\title{
Yield ability and quality of seeds of flax varieties in the Southern steppe of Ukraine depending on different growing conditions
}

\author{
Vozhegova R. ${ }^{1}$, Borovik V. ${ }^{2}$, Konovalova V. ${ }^{3}$ \\ 1,2 Institute of Irrigated Agriculture of NAAS \\ Naddniprianske, Kherson, 73483, Ukraine \\ ${ }^{3}$ Askaniia State Agricultural Research Station of Institute of Irrigated Agriculture of NAAS \\ Tavrychanka village, Kakhovka region, Kherson oblast, 74862, Ukraine \\ e-mail: ${ }^{1}$ izz.ua@ukr.net, ${ }^{2}$ veraborovik@meta.ua, ${ }^{3}$ vera konovalova 1990@ukr.net \\ ORCID: ${ }^{1} 0000-0002-3865-5633 ;{ }^{2} 0000-0002-6507-4006 ;{ }^{3} 0000-0002-0655-9214$
}

Goal. To determine the yield ability and oil content of seeds of different flax varieties under different conditions of moisture and doses of mineral fertilizers in the zone of Southern Steppes of Ukraine. Methods. Field - to determine the dependence of the object of study on human factors and productivity, analysis - to assess the conditions of cultivation, statistical - to calculate and assess the results obtained. Results. At cultivation of flax on different backgrounds of moisture in the droughty steppe of Ukraine, it was established that irrigation provides an increase of seed yield in cultivars Orfei $(0.79 \mathrm{t} / \mathrm{ha})$, Vira (0.82 t/ha), Evrika (1.03 t/ha) with the application of the N90P60. Mineral fertilizing in the dose of N90P60 will provide the maximum yield of seeds of the varieties Evrika, Orfei, Vira with irrigation and without it - 1,33 - 2.36 t/ha; $1,45-2.24 ; 1,47$ $2.29 \mathrm{t} /$ ha respectively. The highest oil content in flax seeds, which made up $46 \%$ on non-irrigated areas, and $47.4 \%$ for irrigation, was obtained from the variety Vira at entering N60P60. Oil yield was 569 and $966 \mathrm{~kg} / \mathrm{ha}$, respectively. Conclusions. For the first time for new flax varieties Evrika, Orfei, Vira in growing for seeds in different conditions of moisture in the dry conditions of Southern steppe of Ukraine it was established that irrigation provides a yield increase of $0.79-1.03 \mathrm{t} / \mathrm{ha}$. With the application of mineral fertilizers in the dose of N90P60 they obtained the maximum seed yield of all the studied flax varieties. It is proved that in conditions of Southern steppe of Ukraine it is better to sow a variety of flax Vira which at entering fertilizers in the dose of N90P60 without irrigation provides a yield of $1.47 \mathrm{t} / \mathrm{ha}$, and oil content of $45.4 \%$. At irrigation, the yield reaches $2.29 \mathrm{t} / \mathrm{ha}$, oil content $-47.4 \%$, which corresponds to $966 \mathrm{~kg} / \mathrm{ha}$.

Key words: Evrika, Orfei, Vira, dose of fertilizer, oil content, non-irrigated and irrigated variants.

DOI: https://doi.org/10.31073/agrovisnyk202003-12

Using the best varieties of linseed oil is one of the effective means of increasing its yield and improving product quality. To choose the best possible from the collections that exist in the world [1].

Flax samples for the gene pool are selected on the basis of genetic diversity studies, phenological, morphological and agronomic features [2-6].

When selecting a variety for cultivation in a particular region, its genetic potential, biological characteristics and uses are to be taken into account [7].

Therefore, it is important to select varieties of flaxseed adapted to the area of introduction, because scientists have found that the external environment and growing conditions have a direct impact on the formation of quantitative traits in plants, including flaxseed (Linum usitatissimum L.) - the duration of the growing season, high vegetation period, plant branching and yield, demonstrating the additivity of gene effects [8-13].

In this regard, we studied new varieties of linseed oil Eureka, Orpheus and Vera, created for the southern steppe of Ukraine.

Depending on the environmental conditions, the fluctuations of oilseeds in the variety can be $36,4-52,0 \%$ $[14,15]$.

Mineral fertilizers greatly influence the accumulation of oil in flax seeds. An important measure of the effectiveness of their use is the choice of optimal doses and the ratio of the main batteries. For new varieties of flaxseed Eureka, Orpheus and Vera, no such studies have been conducted.

Therefore, the purpose of our study was to determine the yield and oilseeds of seeds of different varieties of oilseed flax under different conditions of moist supply and doses of mineral fertilizers in the area of the Southern Steppe of Ukraine.

Materials and methods. The experiments were conducted against irrigation and under irrigation conditions at the field of research of the Askani State Agricultural Agricultural Research Station of the Institute of Irrigated Agriculture of the NAAS in 2015-2018 in the area of the Kakhovka Irrigation System. Predecessor - winter wheat. Repeat three times. There were systematic options. Agrotechnics are generally accepted, except for the factors studied. The main cultivation of the soil under the experiment - plowing to a depth of $20-25 \mathrm{~cm}$. The application of mineral fertilizers was carried out in accordance with the scheme of the experiment. Seed rate is 5 million pieces/ha. Seeding was carried out with a precision seeder "Maple" 1.6. On average, during the growing season, 4 irrigations were carried out with the Zimmatik sprinkler of $300 \mathrm{~m}^{3}$ of water per hectare. 
The soil of the experimental field is dark chestnut hard loamy, partly slightly saline with humus content in the arable layer $2.15-2.3 \%$. Soil density $-1.2-1.3 \mathrm{~g} / \mathrm{cm}^{3}$, wilting moisture $-7.8-9.8 \%$, lowest moisture capacity $0.7 \mathrm{~m}$ layer $20.5-22.4 \%$. Groundwater is more than $15 \mathrm{~m}$ deep.

Annual rainfall ranges from 239 to $969 \mathrm{~mm}$ SCC (according to Selyaninov), which depends not only on the amount of precipitation, but also on the temperature regime, is in the range of 0.5-0.7. The humidity coefficient (according to Buchinsky) is less than 0.5 , which indicates a significant advantage of evaporation over the amount of moisture from precipitation. The number of dry days, when the relative humidity drops to $30 \%$, in the south of the Steppe zone is about 50. That is, in this zone there is a persistent lack of moisture, which confirms the need for irrigation. Therefore, it is no accident that $82.8 \%$ of all irrigated lands of Ukraine are located in the Steppe zone.

It should be noted that the temperature regime of the Steppe zone of Ukraine is quite favorable for obtaining high seed yields provided that the flax is provided with oil moisture. Irrigation water was used for irrigation water of the Kakhovka Irrigation System, which is suitable for irrigation without additional purification (filtration).

The scheme of the experiment provided the following factors and their gradations: factor A - water supply regime (without irrigation and irrigation) factor $B$ - varieties of linseed oil (Eureka, Orpheus, Vera) factor $C$ mineral nutrition background (without fertilizers, $\mathrm{N}_{45} \mathrm{P}_{60}, \mathrm{~N}_{60} \mathrm{P}_{60}, \mathrm{~N}_{90} \mathrm{P}_{60}$ ).

Research methods - field to determine the dependence of the object of research on anthropogenic factors and productivity, analytical - to assess the conditions of cultivation of culture, statistical - to calculate and evaluate the results obtained.

Indicators of seed quality were determined in the laboratory according to conventional methods [16].

Results. Vegetable oil derived from flaxseed has been used for many centuries. Phylogenetic analysis shows that flax was first used to make oil and then to obtain fiber [17].

Flax seed contains up to $48 \%$ of the oil used in the form of technical raw materials for a number of industries: paint, soap, leather and footwear, etc. In the last two decades, flaxseed has been the focus of research in diet and disease because of the potential health benefits associated with its biologically active components [17 19].

Scientists have evaluated the stability of quality indicators in the promising lines of linseed oil. The data obtained prove that one way to increase the amount of oil in flax seeds is to use a mineral fertilizer [20-22].

The results of the study showed that mineral fertilizers, which are an indispensable element of the technology of cultivation of crops, including flax oil, significantly increase the yield of its seeds and affect the content of oil. The indexes of oilseed flax grown for irrigation were slightly higher than in the variants without irrigation. The highest content of oil in flax seeds was obtained in the Vera variety for the application of $\mathrm{N}_{60} \mathrm{P}_{60}$, which was $46.0 \%$ on the rain and $47.4 \%$ on the irrigation. The yield of oil at the same time 569 and $966 \mathrm{~kg} / \mathrm{ha}$, respectively (table 1$)$.

1. Impact of different doses of mineral fertilizers and soil moisture conditions on yield and quality indicators of flaxseed oil seeds, average for 2016-2018

\begin{tabular}{|c|c|c|c|c|c|}
\hline $\begin{array}{l}\text { Growing } \\
\text { conditions } \\
(\text { Factor A) }\end{array}$ & $\begin{array}{l}\text { Sort } \\
\text { (Factor B) }\end{array}$ & $\begin{array}{l}\text { Background of } \\
\text { mineral nutrition } \\
\text { (Factor } \mathrm{C})\end{array}$ & ha Yield, t / & Oilseed,\% & $\begin{array}{l}\text { Oil yield, } \\
\mathrm{kg} / \mathrm{ha}\end{array}$ \\
\hline \multirow[t]{12}{*}{ Irrigation } & \multirow[t]{4}{*}{ Eureka } & $\begin{array}{l}\text { Control (no / } \\
\text { fertilizer) }\end{array}$ & 1,70 & 43,3 & 655 \\
\hline & & $\mathrm{N}_{45} \mathrm{P}_{60}$ & 2,06 & 43,9 & 805 \\
\hline & & $\mathrm{N}_{60} \mathrm{P}_{60}$ & 2,23 & 44,8 & 889 \\
\hline & & $\mathrm{N}_{90} \mathrm{P}_{60}$ & 2,36 & 45,0 & 945 \\
\hline & \multirow[t]{4}{*}{ Orpheus } & $\begin{array}{l}\text { Control (no / } \\
\text { fertilizer) }\end{array}$ & 1,63 & 45,1 & 654 \\
\hline & & $\mathrm{N}_{45} \mathrm{P}_{60}$ & 1,97 & 45,2 & 792 \\
\hline & & $\mathrm{N}_{60} \mathrm{P}_{60}$ & 2,12 & 46,4 & 876 \\
\hline & & $\mathrm{N}_{90} \mathrm{P}_{60}$ & 2,24 & 46,2 & 921 \\
\hline & \multirow[t]{4}{*}{ Faith } & $\begin{array}{l}\text { Control (no / } \\
\text { fertilizer) }\end{array}$ & 1,65 & 45,2 & 664 \\
\hline & & $\mathrm{N}_{45} \mathrm{P}_{60}$ & 2,06 & 45,1 & 827 \\
\hline & & $\mathrm{N}_{60} \mathrm{P}_{60}$ & 2,17 & 46,1 & 890 \\
\hline & & $\mathrm{N}_{90} \mathrm{P}_{60}$ & 2,29 & 47,4 & 966 \\
\hline \multirow[t]{7}{*}{$\begin{array}{l}\text { Without } \\
\text { irrigation }\end{array}$} & \multirow[t]{4}{*}{ Eureka } & $\begin{array}{l}\text { Control (no / } \\
\text { fertilizer) }\end{array}$ & 0,99 & 43,5 & 383 \\
\hline & & $\mathrm{N}_{45} \mathrm{P}_{60}$ & 1,20 & 43,2 & 461 \\
\hline & & $\mathrm{N}_{60} \mathrm{P}_{60}$ & 1,29 & 43,7 & 502 \\
\hline & & $\mathrm{N}_{90} \mathrm{P}_{60}$ & 1,33 & 43,6 & 516 \\
\hline & \multirow[t]{3}{*}{ Orpheus } & $\begin{array}{l}\text { Control (no / } \\
\text { fertilizer) }\end{array}$ & 1,06 & 42,0 & 396 \\
\hline & & $\mathrm{N}_{45} \mathrm{P}_{60}$ & 1,27 & 44,9 & 508 \\
\hline & & $\mathrm{N}_{60} \mathrm{P}_{60}$ & 1,37 & 45,0 & 549 \\
\hline
\end{tabular}




\begin{tabular}{|c|c|c|c|c|c|}
\hline & & $\mathrm{N}_{90} \mathrm{P}_{60}$ & 1,45 & 44,7 & 577 \\
\hline & \multirow[t]{4}{*}{ Faith } & $\begin{array}{l}\text { Control (no / } \\
\text { fertilizer) }\end{array}$ & 1,11 & 42,8 & 423 \\
\hline & & $\mathrm{N}_{45} \mathrm{P}_{60}$ & 1,29 & 45,7 & 525 \\
\hline & & $\mathrm{N}_{60} \mathrm{P}_{60}$ & 1,39 & 46,0 & 569 \\
\hline & & $\mathrm{N}_{90} \mathrm{P}_{60}$ & 1,47 & 45,4 & 593 \\
\hline \multirow{3}{*}{ SSD $_{05}$, т/га } & Factor A & & 0,06 & & \\
\hline & Factor $\mathrm{p} \mathrm{B}$ & & 0,09 & & \\
\hline & Factor p C & & 0,08 & & \\
\hline
\end{tabular}

When growing flaxseed oil seeds on different backgrounds of moist supply in the conditions of the arid Steppe of Ukraine, it was found that irrigation provides an increase in seed yield in the Orpheus variety by 0.79 $\mathrm{t} / \mathrm{ha}$, in the Vera variety by $0.82 \mathrm{t} / \mathrm{ha}$, Eureka - by $1,03 \mathrm{t} /$ ha against application of $\mathrm{N}_{90} \mathrm{P}_{60}$.

The use of mineral fertilizers with a dose of N90P60 ensured the maximum yield of seeds of the varieties of Eureka, Orpheus, Vera both on irrigation and in variants without irrigation $(1,33-2,36 ; 1,45-2,24 ; 1,47-2,29$ t/ha, respectively).

When growing flax of the oil variety Vera for irrigation yield was $-2.29 \mathrm{t} / \mathrm{ha}$ with the highest oiliness of $47.4 \%$, which is only 0.07 t/ha less than the yield of the Eureka variety under the same growing conditions (Fig. 1).

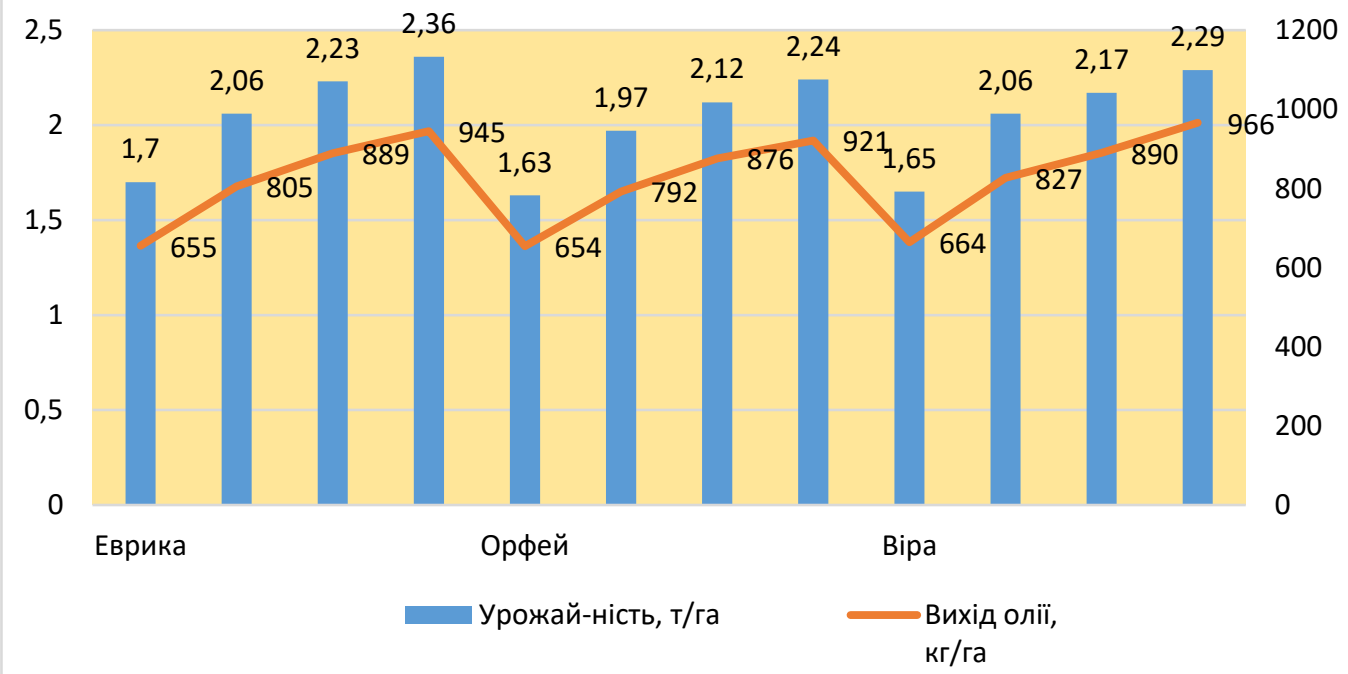

Fig. 1. Output of oil of flax varieties depending on yield in irrigation conditions on the background of different doses of mineral fertilizer

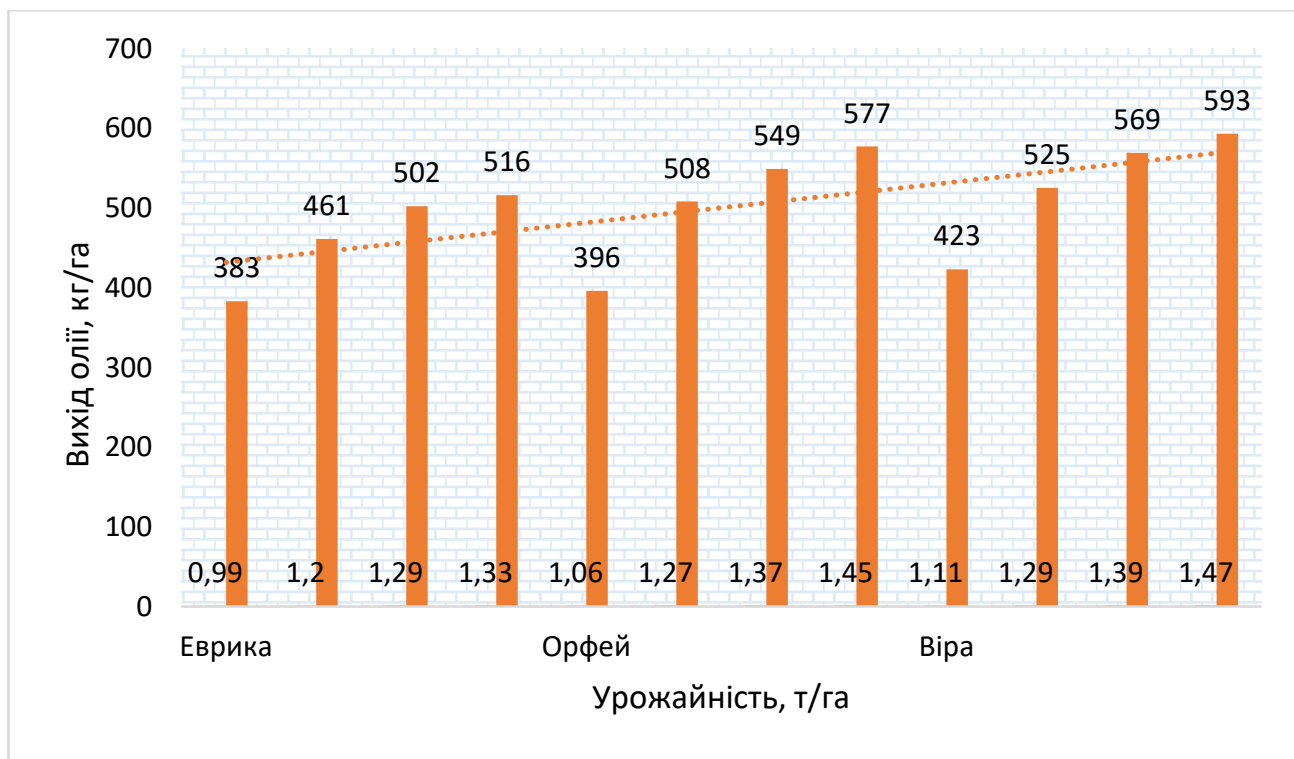

Fig. 2. The output of oil varieties of linseed oil depending on the yield in conditions of natural moistening of the soil against the background of different doses of mineral fertilizer 
Growing flax of the Vera oil variety on the background of $\mathrm{N}_{90} \mathrm{P}_{60}$ under conditions of natural humidity provided the highest yield at the level of $1.47 \mathrm{t} / \mathrm{ha}$, the oil content was $45.4 \%$.

Generalized data on the yield and quality of varieties showed that the variety Vera, created by the State Farm "Askaniye", is one of the most high yielding and adapted to the conditions of southern Ukraine both in terms of natural humidity and irrigation, has a higher content of oil in the seeds, compared with varieties of Eureka and Orpheus.

\section{Conclusions}

For the first time, for new varieties of flaxseed Eureka, Orpheus, Faith, when grown on seeds on different backgrounds of moist supply in the conditions of the arid Southern Steppe of Ukraine, it was found that irrigation provides an increase in yield of 0.79-1.03 tha.

The application of mineral fertilizers with a dose of N90P60 resulted in the maximum seed yield of all the tested flax varieties of oilseed.

As a result of the scientific work, it was found that in the conditions of the Southern Steppe of Ukraine it is better to sow a variety of flax Vera, which when introduced N90 P60 without irrigation provides a yield of 1.47 tha. Oiliness of this variety under such conditions of cultivation is $45.4 \%$. In the case of irrigation, the product of Eureka is more productive, which, with the introduction of $\mathrm{N90}$ P60, provided a maximum yield of 2.36 tha, but with a seed oil content of $45.0 \%$ and oil yield per hectare, $945 \mathrm{~kg}$, inferior to Vera, in whose seed yield is $2.29 \mathrm{t} / \mathrm{ha}$, oil content is $47.4 \%$, which corresponds to $966 \mathrm{~kg} / \mathrm{ha}$.

\section{References}

1. Diederichsen, A. (2001). Comparison of genetic diversity of flax (Linum usitatissimum L.) between Canadian cultivars and a world collection. Plant breeding, 120(4), 360-362. doi: 10.1046/j.14390523.2001.00616.x. [In English].

2. Sahaidak, Ye. O. (2017). Study of the collection of linseed oil by the quality of oil. Modern directions of selection, technologies of cultivation and processing of oilseeds: materials of the international scientific conference [Vyvchennia kolektsii lonu oliinoho za yakistiu olii. Suchasni napriamy selektsii, tekhnolohii vyroshchuvannia ta pererobky oliinykh kultur]. (pp. 40-41). Zaporizhzhia. [In Ukrainian].

3. Diederichsen, A., \& Raney, J. P. (2006). Seed color, seed weight and seed oil content in flax (Linum usita-tissimum L.) accessions held by Plant Gene Resources of Canada. Plant Breed, 125, 372-377. doi: 10.1111/j.1439-0523.2006.01231. [In English].

4. Diederichsen, A., Rozhimina, R. A., \& Kudrjavceva, L. P. (2008). Variation patterns within 153 flax (Linum usitatissimum L.) genebank accessions based on evaluation for resistance to fusarium wilt, anthracnose and pasmo. Plant Genet. Resour, 6, 22-32. doi: https://doi.org/10.1017/S1479262108913897. [In English].

5. Diderichsen, A., \& Ulrich, A. (2009). Variability of stem fiber content and its relationship with other characteristics in 1177 flaxseed (Linum usitatissimum L.) gene bank receipts. Ind. Crops Prod, 30, 33-39. doi: 10.1016/j.indcrop.2009.01.002. [In English].

6. Diederichsen, A., Rozhmina, T. A., Zhuchenko, A. A., \& Richards, K. W. (2006). Screening for broad adaptation in 96 flax (Linum usitatissimum L.) accessions under dry and warm conditions in Canada and Russia. Plant Genet. Resour., 146, 7-14. [In English].

7. Perspektivnaya resursosberegayushchaya tekhnologiya proizvodstva Ina maslichnog: metod. rek. (2010). [Promising resource-saving technology for the production of oilseed flax: a method. rivers]. Moscow: FSU «Rosinformagrotech». [In Russia].

8. Sood, S., Kalia, N.R., Bhateria, S. et al. (2007). Detection of genetic components of variation for some biometrical traits in Linum usitatissimum L. in sub-mountain Himalayan region. Euphytica, 155, 107-115. doi: 10.1007/s10681-006-9309. [In English].

9. Bhateria, S., Court, S. P., \& Patania, A. (2006). Genetic analysis of quantitative traits in the environment. Linna usitatissimum L.). Euphytica, 150, 185-194. doi: 10.1007/s10681-006-9106-7. [In English].

10. Mohammadi, A. A., Saeidi, G., \& Arzani, A. (2010). Genetic analysis of some agronomic traits in flax (Linum usitatissimum L.). Crop Sci., 4, 343-352. [In English].

11. Mpofu, S. I., \& Rashid, K. Y. (2001). Vegetative compatibility groups within Fusarium oxysporum f.sp. lini from Linum usitatissimum (flax) wilt nurseries in western Canada. J. Bot., 79, 836-843. doi: 10.1139/b01058. [In English].

12. Stolarchuk, T. A., Kalenskaya, S. M., \& Kysilchuk A. M. (2017) Porivnialna kharakterystyka morfolohichnykh osoblyvostei sortiv lonu oliinoho v umovakh pravoberezhnoho Lisostepu Ukrainy [Comparative characteristics of morphological features of oilseed flax varieties in the conditions of the rightbank Forest Steppe of Ukraine]. Bulletin of the Poltava State Agrarian Academy, 4, 136-139. doi: 10.31210/visnyk2017.04.27. [In Ukrainian].

13. Tovstanovska, T. H. (2017). Minlyvist oznak yakosti llianoi olii u kolektsiinykh zrazkiv lonu oliinoho $v$ umovakh Stepu Ukrainy: Materialy mizhnarodnoi naukovoi interent-konferentsii [Variability of flaxseed oil 
quality characteristics in collections of linseed oil in the conditions of the Steppe of Ukraine: Proceedings of the International Scientific Inter-Conference]. (pp. 46-47). Zaporizhzhia. [In Ukrainian].

14. Scherbakov, V. G., \& Lobanov, V. G. (2003). Biokhimiya $i$ tovarovedenie maslichnogo syrya [Biochemistry and commodity science of oilseed raw materials]. Moscow: Kolos. [In Russian].

15. Diederichsen, A., \& Raney, J. P. (2006). Seed colour, seed weight and seed oil content in Linum usitatissimum accessions held by Plant Gene Resources of Canada. Plant Breed, 125(4), 372-377. doi: 10.1111/j.1439-0523.2006.01231. [In English].

16. Nasinnia silskohospodarskykh kultur. Metody vyznachennia yakosti DSTU 4138-2002 (2003). [Seeds of agricultural crops. Methods for determining the quality of DSTU 4138-2002]. [Valid from 2004-11-09]. Kyiv: State Consumer Standard of Ukraine (National Standards of Ukraine). [In Ukrainian].

17. Allab, R. G., Peterson, G. W., Merriwether, D. A., \& Fu, Y. B. (2005). Evidence of the domestication history of flax (Linum usitatissimu L.) from genetic diversity of the sad2 locus. Theor. Appl. Genet., 112, 5865. doi: 10.1007/s00122-005-0103-3. [In English].

18. Goyal, A., Sharma, V., Upadhyay, N., Gill, S. \& Sihag, M. (2014). Flax and flaxseed oil: an ancient medicine \& modern functional food. Food Sci., 34, 1-21. doi: 10.1007/s13197-013-1247-9. [In English].

9. Jankauskien, Z. (2003). Laudatory to flax seed. Vilnius. [In English].

20. Hussain, J., Latif Khan, A., Najeeb ur Rehman Zainullah et al. (2012). Proximate and Nutrient Investigations of Selected Medicinal Plants Species of Pakistan. Journal Article., 5, 620-624. doi: 10.3923/pjn.2009.620.624. [In English].

21. Basandrai, D., Basandrai, A. K., \& Sethi, G. S. (1994). Evaluation of flax (Linum usitatissimum) genotypes for multiple-disease resistance. Indian J. agr. Sc., 64(10), 704-707. [In English].

22. Borowiec, F., Zajac, T., \& Kowalski, Z. (2001). Comparison of nutritive value of new commercial linseed oily cultivars for ruminants. Sc J. anim. Feed, 10(2), 301-308. doi: 10.22358/jafs/67985/2001. [In English].

23. Borisyuk, O. D., Antipova, L. K., \& Wild, V. V. (2011). Vplyv pohodnykh umov na vrozhainist lonu oliinoho $\checkmark$ Pivdennomu Stepu Ukrainy: materialy naukovo-praktychnoi konferentsii. Udoskonalennia tekhnolohii vyroshchuvannia silskohospodarskykh kultur v umovakh Pivdnia Ukrainy [Influence of weather conditions on the yield of oil flax in the Southern Steppe of Ukraine: materials of a scientific-practical conference. Improvement of technology of cultivation of crops in the conditions of the South of Ukraine]. (pp. 53-54). Mykolaiv. doi: 10.31210/visnyk2018.04.09. [In Ukrainian]. 